\title{
Influence of potassium on the productivity and quality of potato: A Review
}

\author{
Singh A., 冈 Chahal H. S., Chinna G. S. and Ranvir S.
}

Received: 10.07.2020

Revised: 17.09 .2020

Accepted: 11.10.2020

\begin{abstract}
Potato ranks one of the most important food crops after rice, wheat, and other field crops. A healthy potato crop removes about 1.7 to 2.3 quintals of potassium $\mathrm{ha}^{-1}$, illustrating that the potassium requirement for potatoes is much higher than that of grains. Being a shallow root crop, the effectiveness of using potassium fertilizers on potatoes varies from 50 to 60 percent. Potassium nutrition plays an important role in increasing the potato yield, either due to the formation of large tubers or the increase in the number of tubers per plant. Among the integrated nutrient management in potatoes, farmyard manure improves the absorption and availability of potassium for potato plants. Potassium protects against frost and drought stress in plants and reduces the incidence of diseases or pests. Potassium availability also decreases the concentration of reducing sugar and improves the colour and quality of potato chips. Potassium sulfate improves potato quality better than sources of potassium chloride.
\end{abstract}

Key Words: Efficiency, Growth rate, Potato, Potassium, Production, Quality, Yield

\section{Introduction}

Potato is the fourth most common food crop in the eastern plains of India, after cereals. India is one of the world's largest potato producers and ranks in 2nd place after China. In India, the eastern plains include the eastern states such as Bihar, Assam, West Bengal, Odisha, Jharkhand, and Chhattisgarh account for about half of the area cultivated with potatoes (53 percent) and production (51 percent) of India. However, potato productivity in the eastern plains is below the national average yield of $19.9 \mathrm{t} / \mathrm{ha}$. In order to reach the production forecast, which is estimated to be 35.4 million tonnes of eastern plains by 2030 , the production rate must be increased to $26.2 \mathrm{t} / \mathrm{ha}$ as compared to the current level of $19.1 \mathrm{t} / \mathrm{ha}$ (CPRI, 2011). Balanced fertilization has proven to be a central focus of agricultural production in different agricultural situations and has contributed almost 50 percent to an overall increase in agricultural production. Potato cultivation requires a balanced dose of nitrogen $(\mathrm{N})$, phosphorus $(\mathrm{P})$, and potassium $(\mathrm{K})$ for optimal production (Singh and Trehan, 1998). In the eastern plains, a serious imbalance in the major nutrient application ratio and over fertilization in favour of nitrogen and the lack in application of

\section{Author's Address}

Department of Agriculture, Khalsa College Amritsar-143001 (Punjab)

E-mail.: nandgharia@gmail.com potash containing fertilizers are fairly common among the farmers of that region (Singh and Rai, 2011). The application of potassium has been neglected by most farmers in our country, leading to the continuous depletion of soil potassium (Ladha et al., 2003; Lal et al., 2007). Indian soils are quite high in total potassium, but only a small fraction of it is present in available form, which is due to the dynamic equilibrium between exchangeable and non-exchangeable forms of potassium. The application of high culture intensity and with the elimination of potassium, soils are becoming more potassium deficient, and frequent potassium deficiencies have been observed in cultures in this region (Panaullah et al., 2006). From the studies experimented by Regmi et al. (2002), it has been concluded that due to the improper application of potassium, the imbalance of soil potassium in the agricultural ecosystem and the stagnation of yield would become more pronounced over time.

\section{Potassium buildup in potato}

Potassium content in drymatter varies over time, the part of the plant and cultivar. Potassium content accounts generally at $78 \%$ in tubers at harvest of the total potassium in plant (Fig. 1). Maximum accumulation of potassium occurs between 30 to 60 days after planting in the plains and 65 to 75 days in mountainous areas (Sharma and Sud, 2001). 
Impact of potassium nutrition on potato production in acidic soils of MalepatanPokhra, productivity

Nepal and observed that the height from the highest

The potato plant possesses a shallow root framework, which resembles/is similar to other crops which limit its scavenging ability in the soil regarding the required nutrients. A higher growth rate of potato plants makes them to absorb nutrients (NPK fertilizers) rapidly (Singh et al., 1997). The potato utilizes more potassium as compared to other crops (Trehan and Claassen, 2000). Potato crop take away about 1.7-2.3 quintal of potassium $\mathrm{ha}^{-1}$, stated that potassium demand of potato is superior as related to cereals. Being a shallow root crop, the effectiveness of using $\mathrm{K}$ fertilizer on potatoes ranges from 50 to 60 percent. Khandakhar et al. (2004), studied the role of lime and potassium on the potatoes in an acid field at the Bangladesh Agricultural Research Station, Debigonj and Ponchagor, Bangladesh, and stated that lime and potassium significantly increased the yield of tubers and that the increase in yield was about to 86 percent compared to the control. The lime and $\mathrm{K}$ increased the height of the plant from $47-53 \mathrm{~cm}$ and $45-54 \mathrm{~cm}$, respectively 60 days after planting. Moinuddin et al. (2004), stated that the impact of various levels of potassium fertilizer on the potato at Gurgaon. The growth parameters (plant biomass and tuber growth rate), yield and yield components (tuber weight) were reported as well as the economic parameters that were significantly affected by increased potassium. Al-Moshileh et al. (2005), studied the effect of potassium, nitrogen and potato separation methods in sandy soils and arid environmental conditions at the Al-Qassim region and founded that the increase in potassium sulfate levels resulted in a significantly higher growth and productivity parameters. Kumar et al. (2006), studied the effect of optimizing the potassium requirements for potato chips in cultivars for the west-central plains of the Central Potato Research Institute, Meerut, and the Central Potato Research Institute, Shimla. It was reported that the degree of processing $(45 \mathrm{~mm})$ and the total number of tubers increased with the application of potash and that the different potassium levels did not influence the number of stems and the number of leaves. Adhikary and Karki (2006), conducted a field experiment at NARC, Rampur-Chitwan and Soil Science Division, Khumaltar-Lalitpur to study the influence of potassium on potato crop plant $(33 \mathrm{~cm})$, the number of shoots $(6)$ and the production of biomass $\left(168 \mathrm{~g} \mathrm{plant}^{-1}\right)$ were obtained with application of $100 \mathrm{~kg}$ of potassium $\left(50 \mathrm{~kg} \mathrm{ha}^{-1}\right.$ basal dose and $50 \mathrm{~kg} \mathrm{ha}^{-1}$ coated). Abu-Zinda Ismail (2009), studied the response of potato to potassium and nitrogen fertilization under conditions in the Gaza Strip and stated that the application of $25 \mathrm{~kg}$ of potassium donum ${ }^{-1}$ has been reported to slightly improved yield and other parameters were negligible and positive. Gunadi (2009), observed the potato response to different potassium sources and application methods in West Java Andisols at the Indonesian Plant Research Institute and found that the sources and methods of application of potash fertilizers the affected plant cover, the weeks are taken to crop cover, the dryweight of the plants and the potatoes supplied with potassium sulfate had a higher yield of tubers than those treated with potassium chloride, in particular under division or division associated with a foliar application. Karam et al. (2011), conducted a field trial to study the effect of the potato response to the rates and time of applicability of the potassium in semi-arid conditions and reported that the application of progressive potassium fertilizer from $0-225 \mathrm{~kg}$ of $\mathrm{K}_{2} \mathrm{O} \mathrm{ha}^{-1}$ had significant effect on the yield and yield components of the potato.

Yohana and Carlos (2011), observed that in the potassium $150 \mathrm{~kg} \mathrm{ha}^{-1}$ rates affect the yield and quality of potato in some cultivars. Ali and Singh (2012), studied the effect of the potato towards nitrogen and potassium in alluvial soil in the flat area of south-western Uttar Pradesh at the Raja Balwant Singh College Bichpuri research farm, Agra and concluded that the highest yield of tubers $\left(30.54 \mathrm{t} \mathrm{ha}^{-1}\right)$ was resulted with the highest levels of nitrogen as well as potassium, which was almost two times higher than the yield recorded under control $\left(11.77 \mathrm{t} \mathrm{ha}^{-1}\right)$. A similar trend was observed for the dry matter yield. The absorption of nitrogen, phosphorus, potassium, and sulfur increased significantly with an increase in the rate of application of nitrogen and potassium. Kumar et al. (2012), reported the influence of K levels on the Kufri chipsona-3 on the campus of the Central Potato Research Institute of Modipuram and stated that the treatment of $150 \mathrm{~kg} \mathrm{ha}^{-1}$ potassium dose has significantly improved performance and quality. 


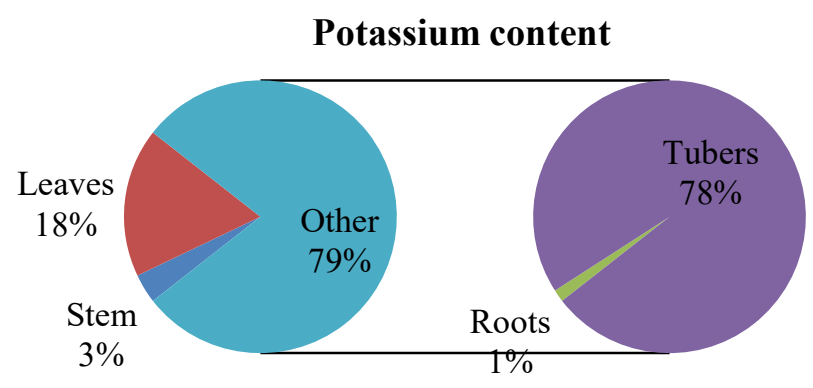

Fig 1. Potassium accumulation in potato plant (Sharma and Sud, 2001)

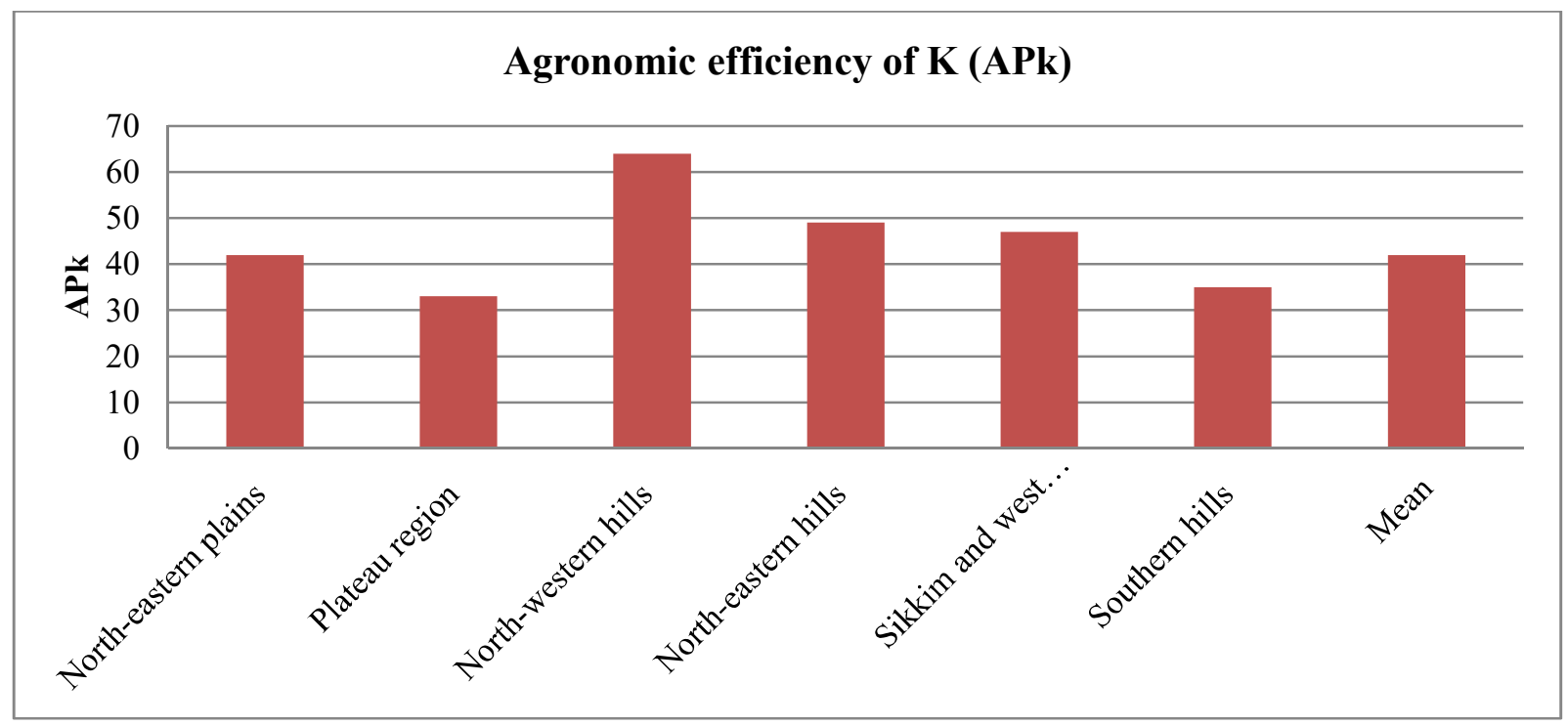

Fig 2. Potassium variability in different agro-climatic zones of India (Tehran, 2007)

Singh and Lal (2012), stated that the increment in potato yield was 19 to 32 percent at 50 to $150 \mathrm{~kg}$ potassium $\mathrm{ha}^{-1}$, respectively, compared to the control. Ghanand et al. (2014), conducted a field experiment on a research farm in Shahrood, Iran, during the 2013 growing season to study the effect of improving the yield and quality of potatoes. Application of potassium sulfate has been reported to increase the dry weight of the root so that the highest dry weight of the root has been observed in plots treated with $500 \mathrm{ml}$ of potassium sulfate and the yield of the plant showed a different trend in response to potassium sulfate levels, therefore the application of $250 \mathrm{ml}$ of potassium sulfate significantly increased the yield of the plant, while the application of $500 \mathrm{ml}$ of potassium sulfate decreased this treatment as comparison to control. Barascu et al. (2015), studied the impact of a high level of potassium on the size structure of the yield and the starch content of the tubers and observed that the higher yield $\left(57.4 \mathrm{t} \mathrm{ha}^{-1}\right)$ was obtained by the use of fertilizers with the primary macronutrient ratio $1: 0.9: 2$ at $200 \mathrm{~kg}$ of nitrogen $\mathrm{ha}^{-1}$. Bhattarai and Swarnima (2016), studied the influence of potassium on the agronomic parameters of potato tubers in Nepal and stated that potassium application had a crucial role in increasing the yield, either due to the large tubers or the increment in the tuber number. Dry matter and specific gravity are more affected by potassium sulfate than potassium muriate (MOP). The application of potassium at $150 \mathrm{~kg} \mathrm{ha}^{-1}$ provides the best economic yield for tubers. The performance increase was greater with the MOP than the SOP. Misgina et al. (2016), concluded that the effect of potassium on the tubers and the yield of potatoes in 
the clay soils of Atsbi - Wenberta and Tigray, Ethiopia, and observed that potassium application has great influence on the yield of tubers.

\section{Variability in the size of tubers relative to} potassium as a source of fertilizer

Tuberization involves the development as well as growth of a stolon, the inhibition of its extension, and the swelling of its tip. Herlithy and Carroll (1969), studied the impact of nitrogen, phosphorus and potassium and their interactions on potato crop at 27 sites, 25 of which were located County or Galway limit and indicated that the size distribution was significantly affected by potassium, increasing the proportion of large tubers and decreasing other grades. Ngomat and Mworia (2017), reported that assessing the influence of potassium fertilizers on potato in Kenya, and stated that the application of potassium chloride influenced weight at different sizes as the ratio of large tubers to small tubers increased and the rate of application of potassium chloride at $250 \mathrm{~kg} \mathrm{ha}^{-1}$ for the Milimani site gave an optimal level of production potatoes.

\section{Potassium efficiency of the potato compared to} other crop species

Potatoes, sugar beets, and wheat are grown in the chamber containing potassium solution of different concentration to explore different $\mathrm{K}$ content scenarios towards dry-matter formation in potato (requires outside K) (Trehan and Claassen, 1998). All crops showed a change in dry matter accumulation with varying concentration of potassium. To achieve 90 percent of the higher accumulated dry matter, potatoes need $40 \mu \mathrm{M}$ potassium, while wheat and radish need 6 and $4 \mu \mathrm{MK}$, respectively. Differences in potassium requirements of crops are not explained by differences in their physiological needs (K concentration in plants must reach near about 90 percent of the maximum accumulation of dry matter) but internal needs of potato are about 1.5 bigger than sugar beets, but its external needs are 9 times bigger than sugar beets. The difference in external $\mathrm{K}$ requirements is largely due to the difference in root system $\mathrm{K}$ absorption efficiency, which seems to be related to the size and flow in the root network. At lower potassium levels, potato plants have low potassium intake and low root/shoot ratio, while wheat and sugar beets showed higher potassium intake, which ultimately leads to high root/shoot ratio. Although the nutrient intake rate and root/shoot ratio of beets and wheat were similar but when $\mathrm{K}$ was deficient, sugar beets produced only $57 \%$ of the dry weight while wheat produced $74 \%$ of the maximum dry weight (Trehan and Claassen, 1998). The lower potassium effect on sugar beets was due to the higher potential growth rate. In an experiment wheat was found to be the most responsive to potassium followed by potatoes and sugar beets. The potassium absorption capacity of wheat is mainly due to the high root: shoot ratio and lower growth rate (Trehan and Claassen, 1998).

\section{Improving the efficiency of potassium in potato} a) Method of applicability of fertilization related to potassium.

Khan et al. (2010), observed the impact of the different sources and levels of potash on the potato crop at the National Center for Agricultural Research (NARC) in Islamabad, Pakistan, and found a significant escalation in yield of tubers with the potassium application $150 \mathrm{~kg} \mathrm{ha}^{-1}$ from the two sources on the treatment with nitrogen and phosphorus and that potassium has improved the yield of tubers and also improved the quality of the product. Potassium application in the form of spray on foliage increased the yield of tubers up to $11 \%$ as compared to that of potassium in the soil-applied to $150 \mathrm{~kg} \mathrm{ha}^{-1}$ of the two sources of potassium, indicating that application of potassium at the ulterior stage of crop growth can compensate for the optimization of the potato yield.

\section{b) Concern over-application of potassium source} on potatoes

Walworth et al. (1990) stated the influence of potassium and other nutrients on the potato at the agricultural and forestry experimental station of the University of Matanuska Farm, South-central Alaska and reported that $\mathrm{K}$ application in the form of chloride or sulfate increased the yield and the chloride applied, and the sulfate had a suitable effect on the specific gravity of the tubers. The application of fertilizers containing chloride reduced the density, contrary to the addition of sulfate ions. Neshev and Manolov (2016), conducted an experiment to study the impact of the levels and the sources related to potassium in the potato and observed that the high level of potassium chloride in the potassium chloride 
variant $\left(200 \mathrm{Kg} \mathrm{ha}^{-1}\right)$ increased the potassium content in aboveground biomass up to 5.16 percent. Kerin and Berova (2008) also showed that potassium is one of the highly needed elements for the potato crops. Abou-zeid and El-Latif (2017), also assessed the effect of potassium on the yield and quality parameters of fertilized potatoes grown on sandy soil in the city of El-Sadat, the governorate of Menoufiea, Egypt, and claimed that the yield and quality of tubers were increased with potassium levels up to $120 \mathrm{~kg} \mathrm{~K}_{2} \mathrm{O} \mathrm{fed}^{-1}$. The highest yield of tubers in the two seasons was 14.85 $\mathrm{fed}^{-1}$ tonnes with potassium sulfate to $120 \mathrm{~kg}$ of $\mathrm{K}_{2} \mathrm{O}$ $\mathrm{fed}^{-1}$ and the application of $120 \mathrm{~kg}$ of $\mathrm{fed}^{-1}$ potassium produced the maximum weight and the diameter of the tuber in all sources of potassium fertilizers.

Specification of location concerning the source of potassium

In different potato growing regionsof India, a large number of experiments were conducted to evaluate the impact of various treatments on potato and its quality (Grewal et al., 1991). The optimization of potassium invarious regions according to the response of the yield of potato in these experiments is given in Fig2. The mean response to the optimal value of potassium was $51 \mathrm{q} / \mathrm{ha}$. The northwest hills had high yields associated with the use of potassium in potatoes compared to other agroclimatic regions of India (Tehran, 2007).

Mohr and Tomasiewicz (2012), conducted a field trial at two locations in southern Manitoba, Canada, to study the effect of potassium application on potato and recorded that application before planting increased the total marketable yield at one location and tended to increase the total yield at three locations and application of chloride potassium on milling decreased the value of small tubers and increased the yield of large tubers.

Interaction of potassium with other nutrients compared to potatoes

a) With organic sources

Ayyub et al. (2011), studied the agronomic response of potato crops to different potash sources at the Faisalabad Agricultural University. Parameters such as days before emergence, percentage of total emergence, and stem number were significantly affected by potassium sulfate, and the performance parameters were significantly higher by the combination of $1 / 4$ Muriate of potash and $3 / 4$ FYM. Organic matter, as well as potassium fertilizers, is essential because the FYM improves the absorption and availability of potassium for potato plants.

\section{b) Sulfur}

Mohan et al. (2017), observed the impact of different potassium levels and sources on the potato at Krishi Vigyan Kendra Kandali, Hassan, Bangalore and revealed that the highest growth parameters such as the plant height (49.0), number of branches (2.83), and total dry matter production $\left(6366 \mathrm{~kg} \mathrm{ha}^{-1}\right)$ recorded with the dose of $75: 75: 175$ $\mathrm{kg} \mathrm{ha}{ }^{-1}$ NPK with potassium in the form of biopotassium + sulfur (S) and the number of tubers and the tuber weight were significantly higher due to the application of 75: $75: 175 \mathrm{~kg} \mathrm{ha}^{-1}$ NPK with potassium in the source of bio-potassium + sulfur (4.80 and 560) and was comparable to 75: 75: 175 $\mathrm{kg} \mathrm{ha}^{-1}$ NPK with potassium in the form of SOP + sulfur (4.6 and 545).

\section{c) Nitrogen}

Shunka et al. (2017), stated the determination of optimal doses of nitrogen and potassium for the production of potato in the highlands of central Ethiopia and observed that potassium levels significantly affected yield parameters as compared to control. The maximum height of the plant was reached when of potassium (34.5 $\left.\mathrm{kg} \mathrm{ha}^{-1}\right)$ and nitrogen $\left(133 \mathrm{~kg} \mathrm{ha}^{-1}\right)$ was applied, whereas the lowest value of the height of the plant was obtainedin treatment in which potassium control and nitrogen $\left(133 \mathrm{~kg} \mathrm{ha}^{-1}\right)$ was applied.

Quality improvement of potato with efficient utilization of potassium source

\section{a) Sugar reduction}

Potassium content plays an important role in increasing the sugar content of potato tubers (Kamal et al., 1974). Sugar concentration was observed higher in tubers treatment with potassiumas compared to nitrogen and phosphorus application alone (Khan et al., 2010). The smallest difference in reducing the sugar content in the potato is obtained at different application levels of $\mathrm{K}$ of MOP, while the largest difference in reducing the sugar content in the tuber of potato is obtained at different $\mathrm{K}$ levels with the SOP application. Bansal and Trehan (2011), studied the Kinfluence on yield and processing quality parameters of potato in different regions of India and found that 
the potato response towards the potassium application revealed an increase in yield from 1.0 to $5.2 \mathrm{t} \mathrm{ha}^{-1}$ at variouslocation in India and that the application of potassium decreased reducing sugars and chip color thinning with low levels of poor nutrition related to potassium.

\section{b) Starch content}

Manolov et al. (2015), observed the impact of the potassium sources on the tuber crop in Bulgaria and reported that the increase in potassium chloride levels more severely reduced the dry matter content vitamin $\mathrm{C}$ and starch in potato tubers, which decreased by 15 percent, 50 percent, and 46 percent in potassium $\left(600 \mathrm{mg} \mathrm{kg}^{-1}\right.$ of $\left.\mathrm{K}_{2} \mathrm{O}\right)$ treatment in the soil respectively compared to the control and they also observed negative correlation between starch content of the tubers andhigher potassium fertilizer rates.

\section{c) Dry-matter of the tuber}

Allison et al. (2001), studied the role of potassium fertilizers on potato crop in various types of soils in England and Wales. The effect of potassium fertilizer on the potassium concentration in the tuber has been reported in various studies. On an average, each tonne of yield in tuber weighs near to $4200 \mathrm{~g}$ of potassium and resulted in significant escalation of tubers dry matter yield. The optimum rate of application of potassium varied from 105 to $250 \mathrm{~kg} \mathrm{ha}^{-1}$. El-Latif et al. (2011), conduct out a field trial at Egypt, to observe the impact of potassium on potato and indicated that increment of potassium levels affects the significant values for all the physiological parameters. It reached the highest values of $\mathrm{N}$ and $\mathrm{K}$ content at 90 days after sowing. While, when $120 \mathrm{~kg}$ of $\mathrm{K}_{2} \mathrm{O}$ fed $^{-1}$ was applied, the high values of tuber yield and protein content were obtained. Pervez et al. (2013), conducted a field experiment in the field of plant research at the Institute of Horticultural Sciences at the Faisalabad University of Agriculture to study the determination of the physic-morphological parameters of the potato regulated by the prudent of potassium and revealed that application of potassium sulfate@150 kg ha ${ }^{-1}$ gave the best results in most parameters (i.e. plant height, weight of the tuber plant ${ }^{-1}$ number of tubers, yield, total dry extract of sugar, dry weight of tubers), while high dose of potassium sulfate don't gave good results concerning the control of certain parameters. Zelelewe et al. (2016), observed that the cultivar

and potassium had a significant impact on the potato physiology and growth parameters increased with increasing levels of potassium from 0 to 150 $\mathrm{kg}$, while days taken to maturity increased in the range 0 to $300 \mathrm{~kg} \mathrm{~K}_{2} \mathrm{O}$ ha $^{-1}$.El-Gawad et al. (2017) studied the impact of potassium silicate on tubers yield and the biochemical components of potato plants facing draught stressin Egypt. Vegetative growth parameters improved significantly using potassium silicate at $2000 \mathrm{ppm}$ foliar which leads to increase in the yield of tubers per plant, total carbohydrates, and dry matter as compared to untreated applications. Kumar et al. (2017), studied the influence of nitrogen and potassium on potato crops at the Faculty of Agricultural and Environmental Sciences, Shobhit University, Gangoh, Saharanpur. They stated that an increase in nitrogen and potash influenced the leaf number and it was concluded that the application of an optimal dose of 150,50 , and $75 \mathrm{~kg}$ of NPK per ha was greater in terms of performance, and more profitable.

\section{d) Specific gravity}

Alisson et al. (2001), also reported that balanced nutrient management with nitrogen, potassium, and phosphorus fertilizers resulted in superior individual tuber density and potato tuber dry matter, which is consistent with our findings.

\section{e) Vitamin $\mathrm{C}$}

The potato tubers treated with $\mathrm{KCl}$ contained less vitamin $\mathrm{C}$ than the control samples treated with $\mathrm{K}_{2} \mathrm{SO}_{4}$. This indicates the harmful effect of $\mathrm{KCl}$ on the vitamin $\mathrm{C}$ content of tubers. $\mathrm{KCl}$ fertilization reduced the vitamin $\mathrm{C}$ concentration to $46 \%$ even at the lowest $\mathrm{K}$ level of $200 \mathrm{mg} \mathrm{K} \mathrm{kg}^{-1}$ of soil. Higher $\mathrm{KCl}$ fertilization rates of $400 \mathrm{mg}$ and $600 \mathrm{mg} \mathrm{K} \mathrm{kg}^{-1}$ of soil reduced the vitamin $\mathrm{C}$ content by $50 \%$ (Manolov et al., 2010).

\section{The response of potassium towards cultivars}

The response of the potato to potassium nutrition is considerably affected by the cultivars (Trehan, 2007). The response of potato cultivars towards potassium is related to their ability to utilize more potassium from the soil. Response of varieties to potassium is generally linked to their potential of yield and quantity or quality of large tubers. In general, potato varieties that produce having vigorous nature respond more to potassium than varieties likely less vigorous, since the application of potassium is known to increase the overall 
growth of potato plant (Trehan and Grewal, 1990).Variety like Kufri Jyoti was more receptive to potassium application as compared to one like Kufri Chandramukhi in West Bengal (Dasmahapatra et al., 1984). Wibowo et al. (2014) also studied the influence of potassium level on the quality characteristics of Indonesian potato tubers in the Serang highlands, Purbalingaa district, Central Java, Indonesia, and found that fertilizer application potassium at $150 \mathrm{~kg} \mathrm{ha}^{-1}$ tends to improve the yield and organic acid content of cultivars. Similarly, the citric acid value of varieties increments up to $2.64 \mathrm{mg}$ per $100 \mathrm{~g}$ when a hundred $\mathrm{kg} \mathrm{ha}^{-1} \mathrm{~K}_{2} \mathrm{O}$ was applied.

\section{Economic dynamics of potassium in potato}

Umar and Moinuddin (2001), conducted a field trial in an agricultural field near Masoori in Uttar Pradesh to study the influence of potassium sources and levels on potato crop and observed that the potassium content in the leaf increased significantly with the applied potassium and showed a positive correlation with the yield of the tubers and that an adequate application of potassium is essential to obtain a maximum economic yield of Potato. Astover and Roostalu (2003), studied the influence of potassium and phosphorus fertilizers on the yield of potatoes according to soil and climatic conditions at the Estonian Agricultural University and reported that in soils having lactate-soluble potassium content less than $130 \mathrm{mg} \mathrm{K}_{2} \mathrm{O} \mathrm{Kg}{ }^{-1}$, moderate amounts of potassium fertilizer increase the yield of the potato almost every year. In soils with high potassium and phosphorus requirements, the cost-effectiveness of potassium or phosphorus fertilizer applications can exceed 140-170 percent.

Frost dynamics of potato concerning with potassium

On the northwest hills the K protects the crop from water stress in the early stages of crop growth under long-day rain conditions. Grewal and Singh (1980), have found that when potassium is present in soil in adequate amounts, frost injury is less for plants, which indicates that there is a negative association between plant potassium and frost damage.

\section{Resistance to disease and pest incidence}

In inclusion to acceptable $\mathrm{K}$, it also provides resistance to downy mildew, a common disease occurring in the hilly regions (Sharma et al., 1999). In addition to this application of potassium, it also decreases the appearance of soil-borne diseases in the potato crop.

\section{Impact on storage or preharvest-losses}

Potassium improves the storability attributes of potato and also prolongs their post-harvest features (Martin-Prevel, 1989). The impact of potassium on shelf life is due to both the minimization of agedness and the decrease in many physiological disorders (Martin-Prevel, 1989). The utilization of potassium minimizes the post-harvest losses of the tubers and this is linked to a decrease in the action of the catalase and peroxidase-like enzymes. The fertilization of potassium tended to gradually minimize the post-harvest loss of potato, which accounts for a 16 percent (Grewal et al., 1991).

\section{Conclusion}

Adopting strategies such as optimal application of $\mathrm{K}$ to potato and techniques for proper handling after harvest is very important to enhance the features of the tubers for better quality and quantity. For better management of nutrients in agriculture, optimum $\mathrm{K}$ fertilization is required. Based on the revised experimental results, it can be mentioned that the application of potassium may be economically recommended for the cultivation of potato planting conditions in potato-producing regions as it has promoted crop production, high yield and greater $\mathrm{K}$ usage efficiency as well as other physiological benefits.

\section{References}

Abou zeid, S. T. and Abd El-Latif, A. L. 2017. Evaluation of Potassium Sources and Rates on the Yield and Quality of Fertigated Potato Grown in Sandy Soil. Egypt Journal of Soil Science, 57(1): 15- 21.

Abu-Zinda Ismail, A. I. 2009. Potato Response to Potassium and Nitrogen Fertilization under Gaza Strip Conditions. Journal of Al Azhar University-Gaza. Natural Sciences, 11: $15-30$.

Adhikary, B. H. and Karki, K. B. 2006. Effect of potassium on potato tuber production in acid soils of MalepatanPokhara. Nepal Agriculture Research Journa, 7: 42-48.

Ali, J. and Singh, S. P. 2012. Response of potato to nitrogen and potassium in the alluvial soil of South-Western plain zone of Uttar Pradesh. Annual of Agriculture Research New Series, 33(1\&2): 40-44. 
Allison, M. F. Flowler, E. J. and Allen, J. H. 2001. Response of Potato (Solanum tuberosum. L) To Potassium Fertilizers. Journal of Agriculture Science, 136: 407-426.

Al-Moshileh, A. M., Errebhi, M. A. and Motawei, M. I. 2005. Effect of various potassium and nitrogen rates and splitting methods on potato under sandy soil and arid environmental conditions. Emir Journal of Agriculture Science, 17(1): 01-09.

Astover, A. and Roostalu, H. 2003. The effect of potassium and phosphorus fertilizers on the potato yield depending on pedoclimatic conditions. LLU Raksti. 8(303): 33-37.

Ayyub, C. M., Pervez, M. A., Manan, A., Akhtar, N., Ashraf, I. and Shahid, M. A. 2011. Growth and Yield Response of Potato Crop to Different Sources of Potash. IJAVMS. 3: 283-288.

Bansal, S. K. and Trehan, S. P. 2011. Effect of potassium on yield and processing quality attributes of potato. Karnataka Journal of Agriculture Science, 24(1): 48-54.

Barascu, N., Ianosi, M., Duda, M. M. and Donescu, V. 2015. The effect of high NPK levels on potato yield size structure and tuber starch content. Scientific Paper Series $A$. Agronomy. 18.

Bhattarai, B. and Swarnima, K. C. 2016. Effect of Potassium on Quality and Yield of Potato tubers - A review. SSRG International Journal of Agriculture \& Environmental Science (SSRG-IJAES). 3(6).

CPRI, 2011. Vision-2030. Central Potato Research Institute,Shimla, India: 40p

Dasmahapatra, A. N., Mondal, S. S. and Pandit, B. C. 1984. Responseto methods of potassium application on the yield of potato inWest Bengal Gangetic plains. Journal of Indian Potato Association, 11: 130-33.

El-Gawad, A. H. G., El-azm, N. A. I. A. and Hikal, M. S. 2017. Effect of potassium silicate on tuber yield and biochemical constituents of potato plants grown under drought stress conditions. Middle East Journal of Agriculture Research, 6(3): 718-731.

El-latif, K. M. A., Osman, E. A. M., Abdullah, R. and Kader, N. A. E. 2011. Response of potato plants to potassium fertilizers rates and soil moisture deficit. Advances in Applied Science Research, 2(2): 399-397.

Ghannad, M., Ashraf, S. and Alipour, Z. T. 2014. Enhancing yield and quality of potato (Solanum tuberosum L.) tuber using integrated fertilizer management. International Journal of Agriculture and Crop Sciences, 7-10: 742-748.

Grewal, J. S. and Singh, S. N. 1980. Effect of K nutrition on frostdamage and yield of potato on alluvial soils of Punjab. Plant and Soil, 57: 105-110.
Grewal, J. S., Trehan, S. P. and Sharma, R. C. 1991 Phosphorus andpotassium nutrition of potato. CPRI Technical Bulletin No.31.Central Potato Research Institute, Shimla, HP, India, p. 43.

Gunadi, N. 2009. Response of Potato to Potassium fertilizer sources and application methods in andisols Of West Java Indonesian Journal of agriculture science, 10(20): 65-72.

Herlihy, M. and Carroll, P. J. 1969. Effects of N, P, and K and their interactions on yield, tuber blight, and quality of potatoes. Journal of Science Food Agriculture, pp 20.

Kamal, M., Khaled, G. and Eskaros, M. 1974. Effect ofgrowth and mineral nutrition on the reducing and nonreducingsugars in potato plants. Agriculture ResearchReview, 52(5): 139-147.

Karam, F., Massaad, R., Skaf, S., Breidy, J. Y. and Rouphael, 2011. Potato response to potassium application rates and timing under semi-arid conditions. Advance of Horticulture Science, 25(4): 265-268.

Kerin, V. and Berova, M. 2008. Leaf nutrition of plants. Publisher "Videnov and son". 124 pages. (In Bulgarian).

Khan, M. Z., Akhtar, M. E., Safdar, M. N., Mahmoood, M. M., Ahmad, S. and Ahmed, N. 2010. Effect of source and level of potash on yield and quality of potato tubers. Pakistan journal of botany, 42(5): 3137-3145.

Khandakhar, S. M. A. T., Rahman, M. M., Uddin, M. J., Khan, S. A. K. U. and Quddus, K. G. 2004. Effect of Lime and Potassium on Potato Yield in Acid Soil. Pakistan Journal of Biological Sciences, 7(3): 380-383.

Kumar, P., Kumar, A., Kumar, N., Ahamad, A. and Verma, M. K. 2017. Effect of integrated nutrient management on productivity and nutrient availability of potato. International Journal Current Microbiology Applied Science, 6(3): 1429-1436.

Kumar, P., Pandey, S. K., Singh, S. V., Kumar, D., Rawl, S. S. and Meena, R. L. 2012. Influence of $\mathrm{N}$ and $\mathrm{K}$ rates on yield and quality of chipping variety Kufri chipsona-3. Potato Journal, 39(2): 191-196.

Kumar, P., Pandey, S. K., Singh, S. V., Rawal, S. and Kumar, D. 2006. Optimizing potassium requirement of chipsona cultivars for west-central plains. Potato Journal, 32(3-4): 155-156.

Ladha, J. K., Dawe, D., Pathak, H., Padre, A. T., Yadav, R. L., Bijay, S., Singh, Y., Singh, Y., Singh, P., Kundu, A. L., Sakal, R., Ram, N., Regmi, A. P., Gami, S. K., Bhandari, A. L., Amin, R., Yadav, C. R., Bhattarai, S., Das, S., Aggarwal, H. P., Gupta, R. K., Hobbs, P. R. 2003. How extensive are yield declines in long-term rice-wheat experiments in Asia? Field Crop Res., 81: 159-81. 
Lal, K., Swarup, A. and Singh, K. N. 2007. Potassium balanceand release kinetics of non-exchangeable $\mathrm{K}$ as influenced by long term fertilizeruse in the rice-wheat cropping system. Agrochimica, 51: 95-104.

Manolov, I., Neshev, N., Chalova, V. and Yordanova, N. 2015. Influence of potassium fertilizer source on potato yield and quality. $50^{\text {th }}$ Croatian and $10^{\text {th }}$ International Symposium on Agriculture.Opatija.Croatia. (363-367).

Martin and Prevel, P. J. 1989. Physiological process related to handlingand storage quality of crops. In Proceedings of the 21st IPI colloqulumon "Methods of K research in plants" held at Louvin-La-Neuve,Belgium 19-21 June 1989. International Potash Institute, Bern,Switzerland pp. 21948Perrenoud, S. (1993). Fertilizing for high yield of potato. IPI bulletin8. Second edition, International Potash Institute, Basel, Switzerland.

Misgina, N. A., Kebede, F. and Abereha, E. 2016. Effect of potassium on Tuber yield and yield compost of potato on Loamy soils of Atsbi-Wenberta, Tigray, Ethiopia. Journal of Biology, 6(3).

Mohan, G. L., Channakeshava, S., Parkash, N. B., Bhairappanavar, S. T. and Tambat, B. 2017. Effect of different rates and sources of potassium on growth, yield, and quality of potato (Solanum tuberosum L.). International Journal of Current Microbiology and Applied science, 6(11): 443-452.

Mohr, R. M. and Tomasiewicz, D. J. 2012. Effect of rate and timing of potassium chloride application on the yield and quality of potato (Solanum tuberosum L. 'Russet Burbank'). Canadian Journal of Plant Science, 92: 783794.

Moinuddin, S. K., Bansal, S. K. and Pasricha, N. S. 2004. Influence of Graded Levels of Potassium Fertilizer on Growth, Yield, and Economic Parameters of Potato. Journal of Plant Nutrition, 27(2): 239-259.

Nagmot, M. S. and Mworia, D. M. 2017. Evaluation of the effects of potassium fertilizer on potato growth and yield in saboti sub-county, tyrant's nzoia county, Kenya. International Journal of Academic Research in Environment and Geography, 4(1): 33-40.

Neshev, N. and Manolov, I. 2016. Potassium fertilizer rate and source influence content, uptake, and allocation of nitrogen, phosphorus, and potassium in potato plants. $4^{\text {th }}$ Conference with International Participation: on Agriculture, Environmentalism, Horticulture, and Floristics, Food production and Processing and Nutrition.

Panaullah, G. M., Timsina, J., Saleque, M. A., Ishaque, M., Pathan, ABMBU., Connor, D. J., Saha, P. K., Quayyum, M. A., Humphreys, E. and Meisner, C. A. 2006. Nutrient uptakeand apparent balances for rice-wheat sequences. III.Potassium. Journal of Plant Nutrition, 29: 173-87.
Pervez, M. A., Ayyub, C. M., Shaheen, M. R. and Noor, M. A. 2013. Determination of physiomorphological characteristics of potato crop regulated by potassium management. Pakistan Journal of Agriculture Science, 50(4): 611-615.

Regmi, A. P., Ladha, J. K., Pasuquin, E., Pathak, H., Hobbs, P. R., Shrestha, L. L., Gharti, D. B. and Duveiller, E. 2002. The roleof potassium in sustaining yields in a longtermrice-wheat experiment in the Indo-Gangetic Plains. Biology and Fertility of Soils, 36: 240-47.

Sharma, R. C. and Sud, K. C. 2001. Potassium management for yield and quality of potato. Pages 363-381 in N. Pasricha and S. Bansal, eds. Proceedings of an international symposium on the role of potassium in nutrient management for sustainable crop production in India. International Potash Institute, Basel, Switzerland.

Sharma, R. C., Sood, M., Imas, C. P., Khan, M. A. and Bansal, S. K. 1999. Nitrogen and potassium interaction on the tuber yield and soil parameter at Shimla. Global Conference on Potato. Indian Potato Assoc., New Delhi. p. 134 (Abstracts).

Shunka, E., Chindi, A. W., Giorgis, S. E. and Tessema, L. 2017. Determination of Optimum Nitrogen and Potassium Levels for potato Production in Central high lands of Ethiopia. De Gruyter Open, 2: 189-194.

Singh, S. K. and Lal, S. S. 2012. Effect of potassium levels and its uptake on the correlation between tuber yield and yield attributing characters in potato (Solanum tuberosumL.) var. KUFRI PUKHRAJ. The Asian Journal of Horticulture, 7(2): 392-396.

Singh, J. P. and Trehan, S. P. 1998. Balanced fertilization toincrease the yield of potato. In, proceeding of theIPI-PRIPAU workshop on "Balanced fertilizationin Punjab agriculture" held at Punjab AgricultureUniversity, Ludhiana, India 15-16 December 1997: 129-139.

Singh, J. P., Trehan, S. P. and Sharma, R. C. 1997. Crop residuemanagement for sustaining the soil fertility and productivityof potato-based cropping systems in Punjab. Journal of Indian Potato Association, 24: 85-99.16.

Singh, S. K. and Rai, R. P. 2011. The potato crop in Bihar: status and future challenges. Electronic International Fertilizer Correspondent (e-ifc). e-ifcNo. 27, June 2011: 1.

Trehan, S. P. and Claassen. N. 1998. External K requirement of young plants of potato, sugar beet, and wheat inflowing solution culture resulting from different internal requirements and uptake efficiency. Potato Research, 41: 229-37.

Trehan, S. P. and Claassen, N. 2000. Potassium uptake efficiency ofpotato and wheat in relation to growth in flowing solutionculture. Potato Research, 43: 9-18. 


\section{Singh et al.}

Trehan, S. P. and Grewal, J. S. 1990. Effect of time and level of potassiumapplication on tuber yield and potassium composition of planttissue and tubers of two cultivars. In: Potato Production,Marketing, Storage, and Processing. Indian Agri. Res. Inst., New Delhi

Trehan, S. P. 2007. Efficiency of potassium utilization from soil asinfluenced by different potato cultivars in the absence andpresence of green manure (Sesbania aculeata). Advances Hort. Sci., 21(3): 156-164.

Umar, S. and Moinuddin, 2001. Effect of sources and rates of potassium application on potato yield and economic returns. Better crops international, 15(1)

Walworth, J. L., Gavlak, R. G. and Muniz, J. E. 1990. Effects of potassium source and secondary nutrients on potato yield and quality in South-central Alaska. Research progress report, AFES publication. 18.
Wibowo, C., Wijaya, K., Sumartono, G. H. and Pawelzik, E. 2014. Effect of Potassium Level on Quality traits of Indonesian Potato Tubers. Asia Pacific Journal of Sustainable Agriculture Food and Energy (APJSAFE), 2 (1): 11-16.

Yohana, C. R. M. and Carlos, E. N. L. 2011. Effects of phosphorus and potassium levels on the yield of the tuber variety Criolla Colombia in the department of Cundinamarca. Agronomía Colombiana, 29(2): 205-212.

Zeid, S. T. A. and El-latif, A. L. A. 2017. Evaluation of potassium sources and rates on the yield and quality of fertigated potato grown in sandy soil. Egypt Journal of Soil Science, 57(1): 15-21.

Zelelewe, D. Z., Lal, S., Kidane, T. T. and Ghebreslassie, 2016. Effect of potassium levels on growth and productivity of potato varieties. American Journal of Plant Sciences, 7: 1629-1638. 